\title{
Regional Councils in a Global Context: Council Types and Council Elements
}

\author{
Anna Growe * (D) and Marilu Jemming \\ Institute of Geography, Heidelberg University, 69120 Heidelberg, Germany; jemming@stud.uni-heidelberg.de \\ * Correspondence: anna.growe@uni-heidelberg.de; Tel.: +49-6221-54-5563
}

Received: 23 December 2018; Accepted: 13 February 2019; Published: 14 February 2019

\begin{abstract}
Propelled by the increasing global competition for location qualities and production factors of (economic) regions in the age of globalization, regional councils have been introduced on sub-national levels in a number of countries. However, the conditions to develop and to govern these regional spaces vary massively in global comparison. Based on three types of elements for the well-functioning of regional councils, in this study, ten regional councils across the globe have been analysed and compared by carrying out qualitative web researches and expert's interviews. Results show that although huge differences between the political organizations in the globally selected case studies exist, two main forms and two sub-types of councils-with a specific functional orientation - can be identified. The aim of the paper is to provide an analytical framework that can be used in analysing regional councils or in processes to develop regional councils further.
\end{abstract}

Keywords: regionalism; regional council; regional governance; comprehensive planning-orientated councils; economic councils; symbolic councils

\section{Introduction: Acknowledging the Regional Level}

Currently, more than half of humankind, around 3.5 billion people, live in cities. According to predictions of the United Nations, this figure is likely to surpass 6.5 billion people by 2050 [1]. Employment possibilities and the availability of functioning infrastructure are factors favouring migration into cities. However, this concentration of people and possibilities in cities also creates challenges with regard to how urban spaces can and should be designed and how governance should be organized in these growing metropolitan regions [2]. Governance should consider the residents' requirements and needs of the regional economy to secure the regions competitiveness within a global economic competition in a globalized world but also take into account environmental and climate objectives and possibilities [3,4].

Accordingly, not only local municipalities, but increasingly (economic) regions compete globally for location qualities and production factors $[5,6]$. With regard to global economic flows and the living and commuting patterns of inhabitants, the importance of municipal boundaries is reduced and functional regions are created, which partly exist in spatial contexts beyond traditional administrative boundaries $[7,8]$. However, the conditions to develop and to govern these regional spaces vary massively in global comparison.

The most important factor for the development and government of the regional level is, of course, how far the existence of a regional level-as being intermediate between the local municipal level and the state level-is acknowledged and fortified $[9,10]$. In a globalised and economically specialised world, regions are gaining in importance, because the day-to-day life and economic activities increasingly extend beyond a single city or municipality [11,12]. However, locally grounded knowledge of responsible actors is necessary to ensure the development of precisely tailored strategies [13]. In this regard, the regional level is seen as a necessary complement to the municipal 
and national level of decision taking. Fortifying the regional level can be explained by the claim of political actors to strategically influence socio-economic developments and their spatial appearance beyond the sometimes limited and locally grounded interests of municipal actors [14]. Therefore, cooperation needs to overcome municipal boundaries and can result in creating new constellations of stakeholders $[15,16]$.

Summing up, in recent decades, regions have been discussed as important spatial configuration enabling an effective dealing with both, global and local challenges [17-19]. However, while regions are understood as actual or potential sub-national political units-be they administrative or governmental or take another of their various forms (for example, cultural, economic, and historical) [20,21]—there does not exist a final definition of regions in the scientific literature. As Harrison states [22], regions are "often assumed, rarely defined" and remain an "object of mystery" [23].

Nevertheless, urban or metropolitan regions are acknowledged as an increasing important spatial configuration and become even more important. Structural changes in the economy-namely the rising knowledge economy-lead to changing spatial patterns of economic activities and support metropolization processes [24-26]. Additionally, continuing migration processes into urban areas emphasise the importance of (metropolitan) regions, leading to new challenges in providing infrastructure and liveable environments [27]. This is also reflected in the scientific discussion of regions. The overwhelming part of the literature deals with the manifold formations of urban or metropolitan regions and governance possibilities in these spaces [10,28-33].

Although the regional level-and especially metropolitan regions-is regarded as important spatial configuration, the question remains how to govern these spaces [34]. "It is often assumed that traditional institutions of government are not up to the task of effective regional governance because there is a mismatch between the scale of government institutions' responsibilities and the extent of the problems that need to be addressed" [35].

Within the diverse possibilities of governing metropolitan regions-from developing "hard structures" by changing existing administrative and governance systems till governing by soft mechanisms through, e.g., developing spatial visions [15,16] or influencing discourses [36]—one possibility is the creation of regional councils [35,37]. Grigsby (1996) emphasises regional councils as one of the mechanisms thought capable of meeting changing challenges posed by changing global conditions [38]. The aim of this paper is to understand regional councils in a global context. To understand regional councils, factors influencing their success are systematized and examined.

\section{Regional Councils}

Propelled by the developments in the age of globalization mentioned previously, many countries have created regional councils [37,39]. Regional councils are understood as a multi-service entity with state and locally-defined boundaries that delivers a variety of federal, state and local programs while continuing its function as a planning organisation, technical assistance provider and 'visionary' to its member local governments [35]. However, the understanding of regional councils is not static. "It should be fairly evident at this point that the role that regional councils play has changed significantly over the past thirty years. In the coming years, they undoubtedly will undergo even more changes" [38]. This fact implies that a final definition of regional councils is less important than an understanding of their functioning mechanism.

Understanding the functioning mechanisms of different regional councils across the globe with regard to successfully establishing them in the future, is one of the main objectives of the present research. To explore the regional councils considered in this study the following analytical framework is developed. Based on criteria drawn from the literature [35,37-42], the following questions are used to develop an analytical framework: How does the regional council work and how is the work legitimated?

The regional council's possibilities to work can be traced back to people and other work-supporting element. Legitimation can be gained through election and nomination procedures. 
However, the legitimation of the councils' work is supported by the services the councils provide and the topics they cover for the regions' benefit.

Therefore, follow-up questions are:

- With regard to people in the regional council: How are the members of the council selected? How do they work together? In a general assembly? In specific committees?

- With regard to supporting elements for the regional councils: How is the council supported? Does administrative support through qualified staff exist? Does financial support exist?

- With regard to services provided by the regional council: What is the outcome of the work of the regional council? What services are provides for the involved municipalities, for the citizens?

- With regard to topics covered by the regional council: What topics does the council deal with? Is there a differentiation made between mandatory and voluntary topics? Are topics prioritized? Who decides which topics have to be worked on?

Moreover, regional councils require executive powers to implement their agendas [43]. Elements helping to answer the questions above are systematized in the following analytical framework, focussing on three main categories:

- key organizational elements,

- $\quad$ aspects regarding the legitimation of regional councils, and

- operational aspects pointing to aspects that help reaching the aims of regional council.

\subsection{Organizational Aspects}

Policy leadership at a regional level provided by policy boards consisting of locally elected officials ensures accountability and promote clear communication and a responsible leadership. Next to political leadership, administrative and technical capacity is also needed. Committees involving elected officials and professionals with a technical background from local, state, and private organisations combine policy and technical knowledge in order to improve the region's development [44]. However, the organisational structure of these committees can differ: some regional councils have a hierarchal structure where most of the powers are vested in few members, while others follow more horizontal models, depending on the size of the regional council, the number of staff, or the number of subcommittees and other internal bodies [44]. With a focus on the implementation of policies and strategies, professional in-house staff providing administrative and technical support for the planning processes of the policy and technical committees is necessary, as are technical capabilities within the council's organisation that allow for the analysis of regional and local problems. One of the most important factors in well-functioning regional councils is a stable source for financing council operations. In some cases, the fiscal stability of the regional councils is enabled by financial support through the federal or the state level. Additionally, many regional councils opt to raise funds through fees and taxes themselves [35,44].

\subsection{Aspects of Legitimation}

Next to organizational elements of regional councils also aspects of legitimation and operational aspects are elementary. Essential are clear governance regulations. Clear governance regulations will result in an efficient platform for the delivery of their services, as the regulations will ensure that the work of the councils will complement other governmental institutions and will insure that there is no overlap [35]. Clarity will reduce the potential for conflicts between governance structures, and encourage a stable environment for cooperation and development. This way, regional councils also have the ability to shape public policy on the regional and/or national level. Lobbying and planning across regional councils nationwide can influence the direction of policymaking at higher levels. For example if councils within one country begin to implement similar policies, either individually or in concert, this may prompt the government to consider incorporating new ideas nationwide. 
This process is illustrated by the American jurist and Supreme Court Justice L. Brandeis who once called the fifty US states 'laboratories' where new ideas could be tested to determine their applicability to other states or the nation as a whole.

In that context it is necessary that regional councils have the opportunity to work on broad thematic topics [41]. Areas of possible programmatic involvement include issues of transportation, issues of the environment, emergency planning, land use, social services, housing, economic development, and public safety [39]. However, possible issues are not limited to the topics mentioned in the list.

\subsection{Operational Aspects}

To facilitate the identification of important issues and to work on the identified issues effectively, a clear vison-developed in the regional council-helps [16,45,46]. This vision should offer a clear framework that assists regional councils in their work and provides them with legitimacy when they work closely with business sector and non-profit institutions. The implementation of strategies and policies point to the need of an availability of external resources in the form of regional social capital [35]. Regional social capital assists the regional councils' abilities to mobilize different sectors in the region. Using regional social capacity, regional councils are more likely to play a collaborative role and implement a form of network governance in which regional councils act as a facilitator and coordinator of partnerships between economic, governmental and non-government actors [38]. Therefore, the likelihood of achieving the regional council's development plans and visions can be increased. Further activities of regional councils can be carrying out technical analyses and serving as data provider to facilitate information exchanges to support collective efforts within the region. In addition, operating citizen participation programs to enlarge the understanding and acceptance of plans and visions developed by the regional council is useful [47].

Summarizing relevant elements for well-functioning regional councils, Figure 1 provides an overview of the three main aspects: organizational elements, legitimation, and operational aspects.

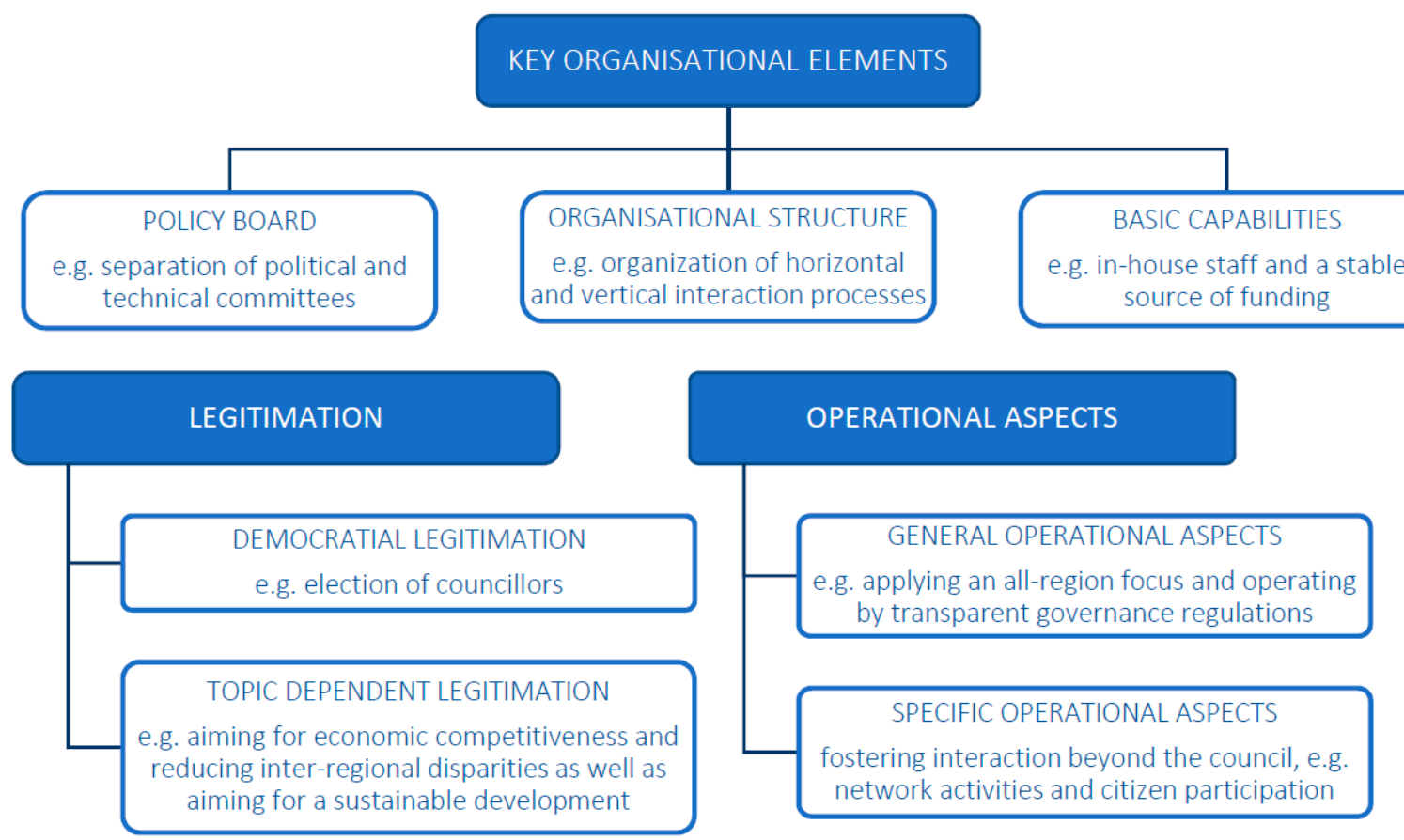

Figure 1. Analysing scheme based on the identified council elements. Source: Own diagram. 


\section{Research Methods}

The aim of the paper is to develop an analytical framework that can be used to understand and to develop further regional councils in different countries. Therefore, possible elements for well-functioning regional councils have been identified through searching scientific literature. The considered elements have been presented in detail in Section 2 (Regional Councils). An overview of the identified elements is given in Figure 1. For analytical purposes, sample elements have been summarized from the literature and a list of indicators assigned with the different categories has been used in the empirical work. Table 1 lists indicators that have been looked for during the empirical work.

Table 1. Indicators to evaluate subcategories of regional councils.

\begin{tabular}{|c|c|c|}
\hline Main Aspect & Subcategories & Indicators \\
\hline \multirow[b]{3}{*}{ Organizational Elements } & Policy Board & Political and technical committees: Do they exist? Are they separated? \\
\hline & Organizational Structure & $\begin{array}{c}\text { Organization of horizontal and vertical interaction processes: Who is included in } \\
\text { interaction processes? How is the process organized? }\end{array}$ \\
\hline & Basic Capabilities & $\begin{array}{l}\text { In-house staff: Is staff available? Is administrative support provided by the } \\
\text { available staff? Is technical support provided by the available staff? } \\
\text { A stable source of funding: Is a stable source of funding given? Where does the } \\
\text { funding come from (e.g., provided by other administrative levels or risen as tax } \\
\text { or contribution by the region?) }\end{array}$ \\
\hline \multirow[b]{2}{*}{ Legitimation } & Democratic Legitimation & $\begin{array}{c}\text { Election of councillors: How are the councillors elected? How long is the election } \\
\text { period? Who elects the councillors? }\end{array}$ \\
\hline & Topic Dependent Legitimation & $\begin{array}{c}\text { Is the work of the council legitimated by the topics the council is working on? } \\
\text { Does the council: } \\
\text { Aim for regional economic competitiveness? } \\
\text { Reduce inter-regional disparities? } \\
\text { Aim for an endogenous, balanced and sustainable development? } \\
\text { Solve specific regional challenges? } \\
\text { Complete regional planning processes? } \\
\text { Undertake technical analyses that serve as regional knowledge resource? }\end{array}$ \\
\hline \multirow{2}{*}{ Operational Aspects } & General Operational Aspects & $\begin{array}{c}\text { Does the council work transparent and on behalf of the region? Does the council: } \\
\text { Apply an all-region focus? } \\
\text { Operate by transparent governance regulations? } \\
\text { Follow a clear framework (visions, missions, processes)? }\end{array}$ \\
\hline & Specific Operational Aspects & $\begin{array}{l}\text { Does the council foster work beyond the council and its embeddedness in } \\
\text { governance structures? Does the council: } \\
\text { Support network activities in the region? } \\
\text { Support and apply citizen participation? }\end{array}$ \\
\hline
\end{tabular}

Using the developed analytical framework, an empirical analysis of regional councils worldwide has been carried out. This analysis consisted of two steps: the first step included the identification of possible case regions where the application of the elements could be analysed, and the second step consisted of a qualitative analysis of the application of the developed elements in ten case regions.

A lot of research dealing with regional councils of discussing governance structures and processes focusses on cases in the United States or in Europe [2,14,36,38,48-52]. To overcome this research bias, a differentiation of five global areas has been set in advance: North America, South America, Europe, Asia, and Africa (see the five coloured sections in Figure 2). During the selection of case regions it was aimed to identify at least two case regions in each global area but only one case region for one country.

For the identification of the relevant case studies, first, qualitative web researches were carried out. The names of nation states in the five global areas, regions and capital urban regions in countries in the five global areas were entered into the search engines in combination with the keyword "regional council". The aim was to identify regional councils beyond the well-known examples from the US and from Europe. As a result, two regional councils in each global area could be identified. However, a bias towards English-speaking countries has to be admitted, as the results depended on the availability of information on potential regional councils in the form of English-language websites. Therefore, the web-search for information on the individually identified Regional Councils was more effective in the English-speaking areas (North America, Australia, New Zealand and Canada) than in the non-English-speaking areas (South America, Africa and Arabic Peninsula). Information on regional councils in Europe was easy to find, too. 


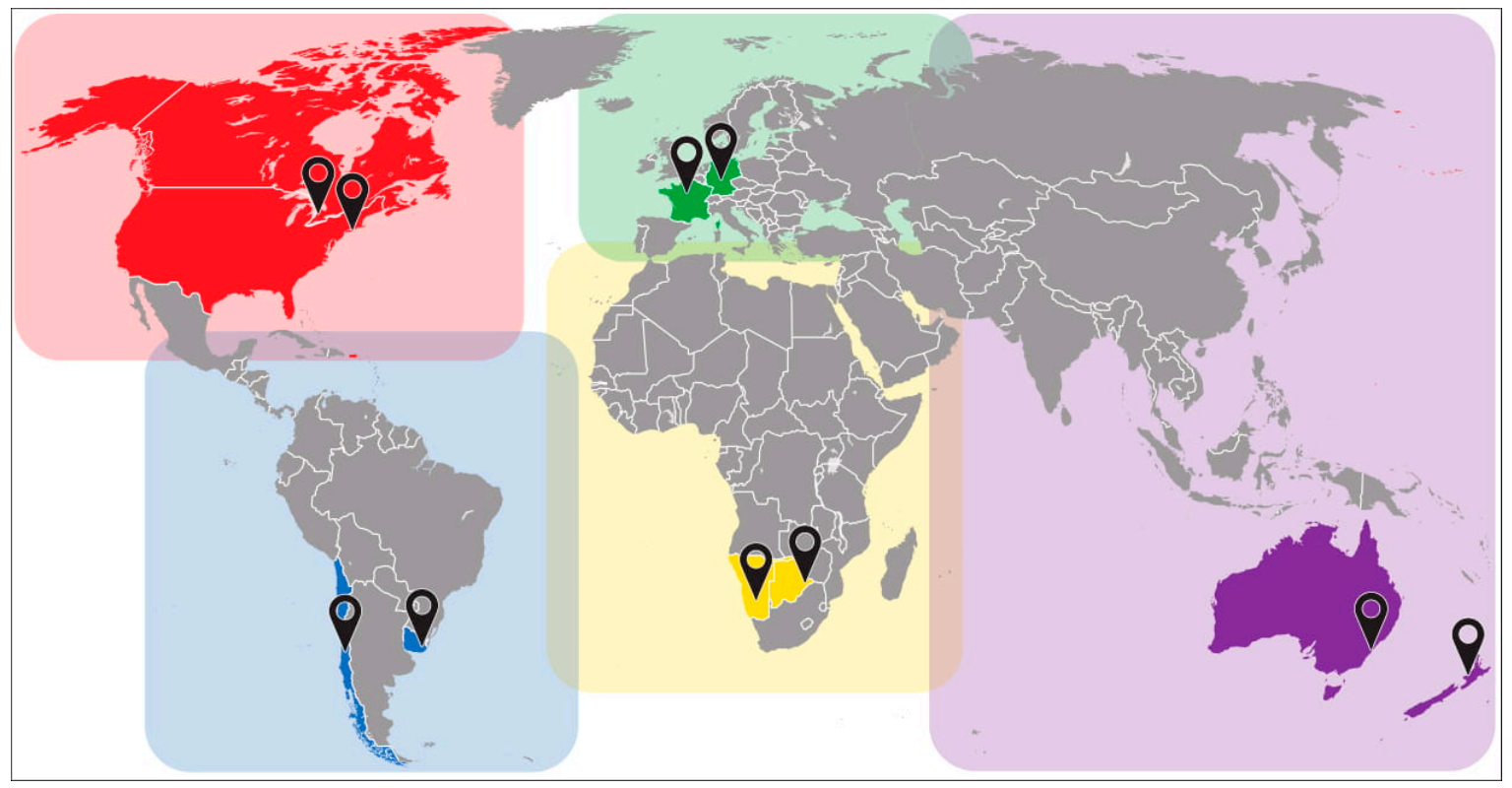

Figure 2. Cartographic overview displaying the selected cases. Source: own design.

Information on websites and within online accessible documents of the possible case regions was then searched for information necessary to apply the analytical framework. Only regions were taken into consideration where at least one aspect to each of the three main criteria (organizational aspects, aspects of legitimation, and operational aspects) was described more in detail. The selected ten case regions are listed in Table 2. These regions and their regional councils were the basis for further analysis.

Table 2. Selected cases.

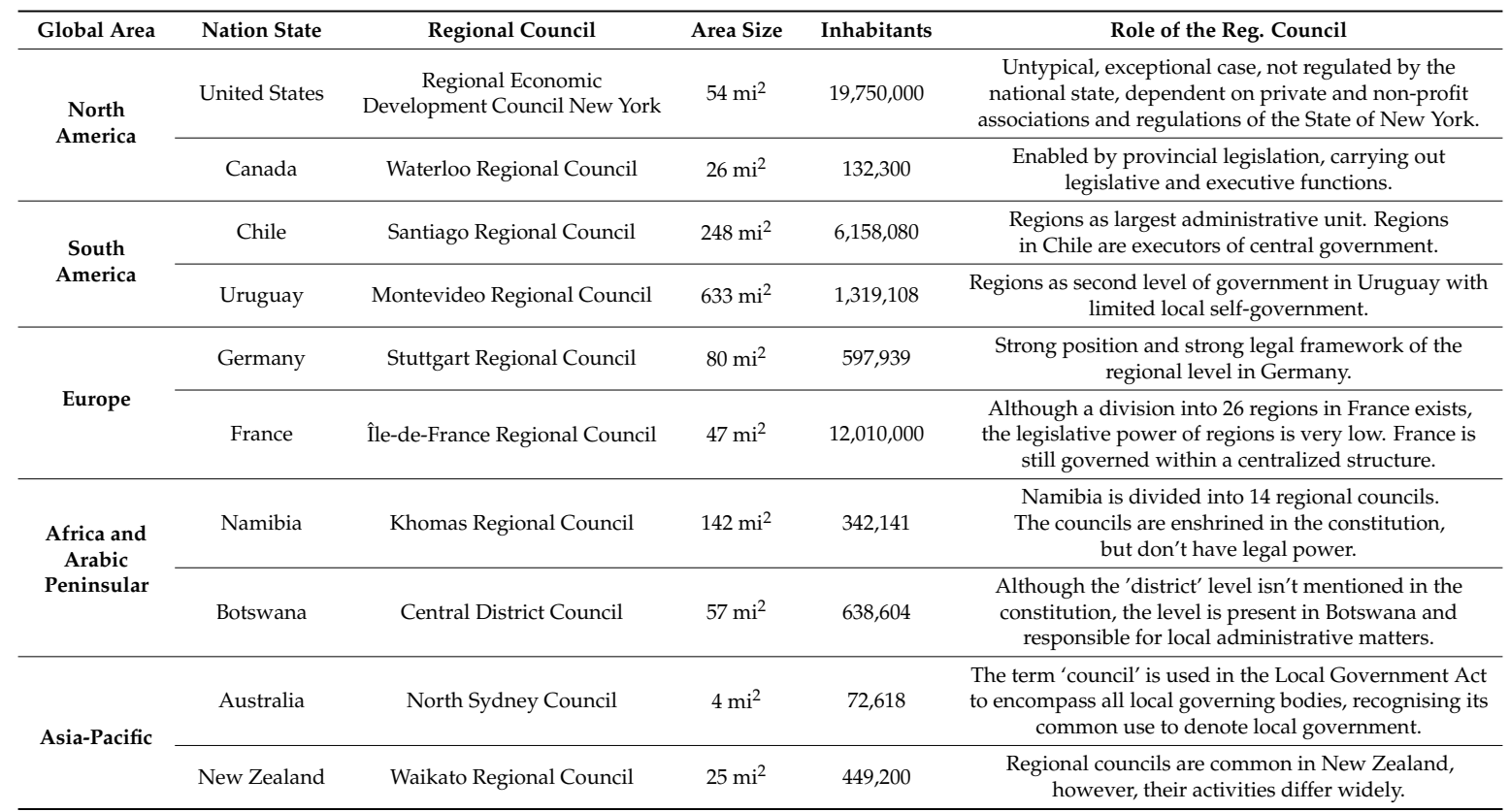

For the qualitative analysis of the selected case regions, evaluation of accessible documents and interviews was used to understand how the three types of elements are applied in the regional councils. The analysis of regional documents was carried out for each selected region. Within the analysis, the official websites of the selected regional councils and regional documents containing information 
on the organization and aims of the councils were included. The aim was to identify how the respective regional councils perform in the three types of elements. The content was qualitatively interpreted on a scale of high, medium or no performance.

To gain a more detailed understanding of the councils, semi-structured interviews were carried out with councillors and technical directors of the councils. All selected regions were asked to participate in a semi-structured interview. Six of ten regions were willing to conduct a telephone interview or to answer a questionnaire (see Table 3). The telephone interviews and the questionnaire contained the same questions. However, as expected, answers in the telephone interviews were much more detailed than answers in the written questionnaire.

Table 3. Regions answering with questionnaire or interview.

\begin{tabular}{ccc}
\hline Country & Regional Council & Positive Response in form of \\
\hline Canada & Waterloo Regional Council & Questionnaire \\
Uruguay & Montevideo Regional Council & Telephone interview \\
Germany & Stuttgart Regional Council & Telephone interview \\
France & Île-de-France Regional Council & Telephone interview \\
Botswana & Central District Council & Telephone interview \\
New Zealand & Waikato Regional Council & Telephone interview \\
\hline
\end{tabular}

The interviews and questionnaires started with questions covering basic information of the three main criteria (e.g., questions dealing with organizational elements have been introduces with 'Please describe the organizational aspects of your council in its current form'), and then moved on to more specific questions (e.g., 'What is the best organizational aspect according to you?'). A list of questions being answered within all questionnaires and interviews is summarized in Table 3. However, within some questionnaires, and in all interviews, deeper questions were covered.

Apart from basic information with regard to the three main criteria (organizational elements, legitimation, and operational aspects), interviews and questionnaires were used to get an evaluation beyond the description of organizational structures that can also be found in documents or on websites. Therefore, questions also covered strengths and weaknesses with regard to the organization of the respective regional councils, an assessment of the challenges that the regional council is facing and about how processes of interaction with different levels of government, as well as with other stakeholders such as the private sector and non-governmental organizations (NGOs) is organized. Table 4 summarizes topics and sample questions of the questionnaire.

Table 4. Topics and sample questions of the questionnaire.

\begin{tabular}{cl}
\hline \multicolumn{1}{c}{ Topic } & \multicolumn{1}{c}{ Sample Questions } \\
\hline Questions dealing with organizational elements & $\begin{array}{l}\text { Please describe the organizational aspects of your council in its current form. } \\
\text { What is the best organizational aspect according to you? } \\
\text { What changes would you recommend? }\end{array}$ \\
\hline $\begin{array}{c}\text { Questions dealing with the councils' } \\
\text { (topic-dependent) legitimation }\end{array}$ & $\begin{array}{l}\text { What are the challenges facing your council? And how does the council contribute to solutions? } \\
\text { Please tell us about a project or a plan that your regional council is proud of. } \\
\text { Please tell us about a project or plan that didn't go so well. } \\
\text { What changes would you recommend assisting you facing these challenges? }\end{array}$ \\
\hline \multirow{2}{*}{$\begin{array}{l}\text { Duestions dealing with operational aspects council have a multi-level governance mechanism? Can you explain it? } \\
\text { Does your council have the ability to shape public policy on a regional/national level? } \\
\text { Does your council lobby on its behalf and for your region at the national level? } \\
\text { Does the council interact with different players of the public sector, with stakeholders of the } \\
\text { private sector or with NGOs? }\end{array}$} \\
\hline
\end{tabular}

To systematize the information gained and to understand what role the three main criteria do play in each regional council, an evaluation of each of the seven criteria (two or three subcriteria to each of the three main criteria, see Figure 1 and Table 1) has been conducted. The evaluation is based on a scale from 0 to 2 . A subcriteria within one regional council is rated 0 if the elements, necessary to perform the respective subcritera, are not present. If some but not all elements, necessary to perform the respective 
subcritera, could be identified as present in the empirical work, the respective subcategory is rated as 1. If all elements supporting a subcritera could be identified as present, the subcategory is rated as 2 (the highest score). The identified values could be used within radar charts to visualize similarities and differences between the analysed councils.

Figure 3 provides an example. The Regional Economic Development Council New York scored 2 on six of the seven subcriteria. Only in the subcriteria 'democratical legitimation' did the council score 1 . This can be explained by the specialized work of the council. Local officials working in the council are appointed not elected. The council is composed of political and technical committees which are organized in public-private partnerships made up of local experts and stakeholders from business, academia, local government, and non-governmental organizations. As democratic legitimation is given partly (elected stakeholders from the local government play a role as nominated part of the council), but no election guarantees a fully democratic legitimation of the councils, the subcategory has been rated 1 (see Figure 3).

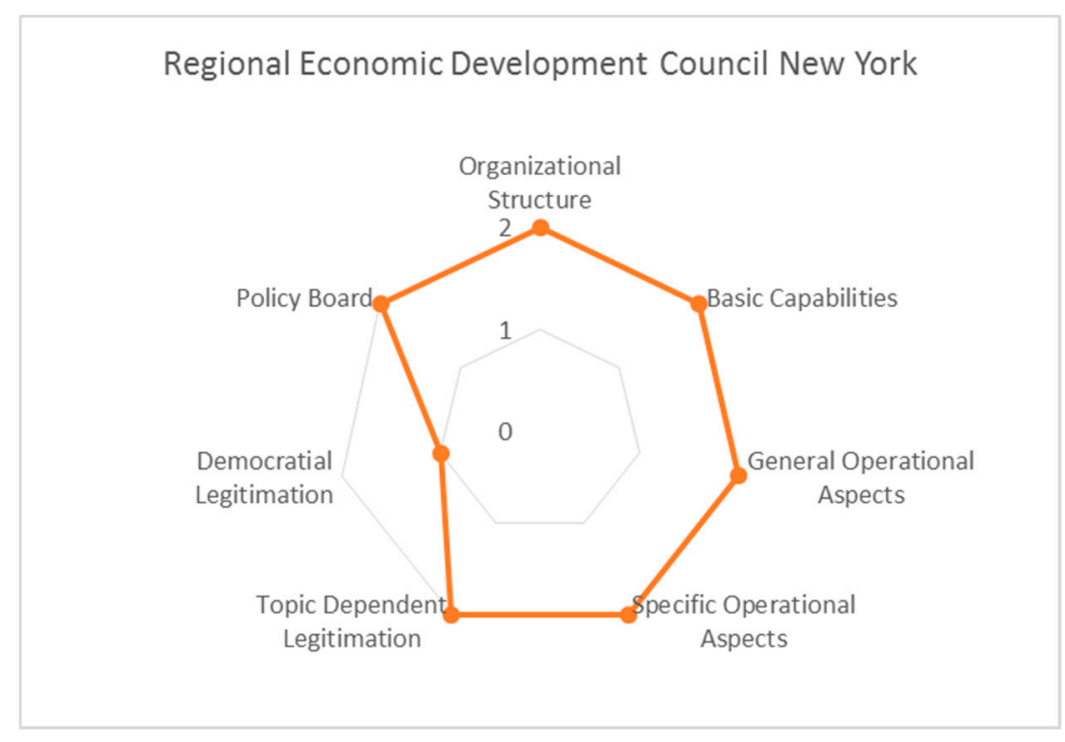

Figure 3. Reading sample: radar chart of the Regional Economic Development Council New York.

Summarizing the methodological approach, the steps of the analysis have been carried out as follows:

- In a first step, the webpages of the sample regions have been searched for information shedding light on how the three main criteria (organizational aspects, aspects of legitimation, and operational aspects) are performed in the respective sample region (see list in Table 1).

- In a second step, additional information of and (subjective) evaluations about the three main criteria have been gained through semi-structured interviews and questionnaires.

- In a third step, information gained in interviews and questionnaires have been back-checked through a search within documents and on webpages.

- In a fourth step, the gained information has been related to the subcategories and each subcategory has been evaluated 2, 1, or 0 for each regional council.

\section{Results}

Results show, that although huge differences between the organizations of the globally selected case regions exist, two main types of regional councils can be identified. The first main type includes regional councils with general administrative functions and the second main type includes regional councils with comprehensive governance functions (with an emphasis on regional planning). Furthermore, two councils with a specific distinct orientation could be identified. However, 
the distinctive focus of the two regional councils with distinct orientation differs: one regional council focusses on economic aspects and deals with the distribution of regional funds and another regional council performs a rather symbolic role. The types of councils have been identified on the basis of the evaluation of subcategories in all councils.

\subsection{Regional Councils with Comprehensive Governance Functions}

Only two councils scored 2 in every subcategory: Stuttgart in Germany and Santiago in Chile (see Figure 4). Having in mind the councils' emphasis on its role as regional planning association ("Our responsibilities are special. The special feature lies in the fact that there are planning responsibilities: we have responsibilities for mandatory planning" (telephone interview, Head of Administration of the Verband Region Stuttgart)), the councils have been summarized as councils with comprehensive governance functions (with an emphasis on regional planning).

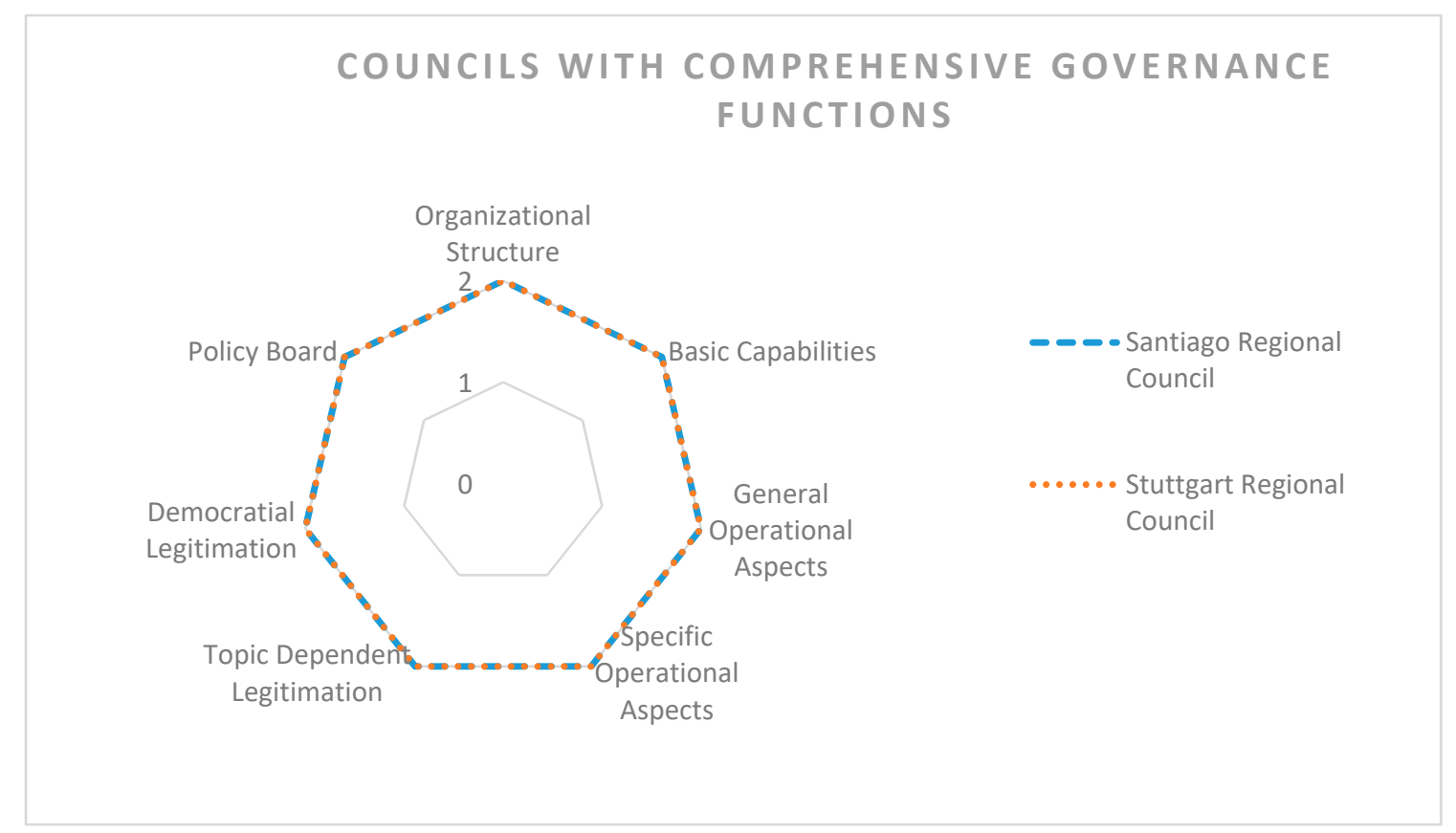

Figure 4. Radar charts for councils with comprehensive governance functions. Source: own design.

Regional Councils with comprehensive governance functions with an emphasis on regional planning, handle a broad range of topics and aim for a strategic development of the respective regions as liveable and economic locations. The regional councils of Stuttgart and Santiago could be understood as regional councils with comprehensive governance functions with an emphasis on regional planning. Topics on the agenda of these councils-and also partly financed-are housing, commercial area development, regional transport planning, landscape planning, and business and tourism development. Fundamental strategic decisions can be taken in the councils, depending on the council's programmatic involvement in the different topics to ensure the region's best development.

In international scientific literature, Germany is well-known as a federally organised nation state, where spatial planning is anchored strongly at the regional level [53]. When it comes to comprehensive planning, development and implementation of plans for land use and infrastructure across a number of sectors takes place at the regional level $[54,55]$. For example, the Stuttgart Regional Council, Germany (called Regional Assembly in Stuttgart) is part of the Verband Region Stuttgart that is the political entity for the Stuttgart Region [56]. The mandatory tasks given to the Verband Region Stuttgart by law include key issues such as regional planning, local public transport, regional transport planning, landscape planning, business and tourism development and certain aspects of waste management. 
In terms of voluntary activities, the Verband Region Stuttgart is allowed to get involved in sport and culture, among others.

The Verband Region Stuttgart fulfils all required key organizational elements from the literature. The legally defined tasks are performed by the regional assembly, the honorary chairperson (chairing the regional assembly) and the full-time regional director (also head of the administrative units). Political executive power is performed in the regional assembly by a maximum of 96 elected officials. The administration of the Verband Region Stuttgart-led by the Regional Director-supports the work of the councils with a staff of about 60 employees. The main competences in the Verband Region Stuttgart are summarized by the Head of Administration in the interview as follows: "So, we have three pillars of regional competence, which are: (i) the mandatory planning, (ii) spatial development and infrastructure, and (iii) the wide range of advertising, promotion, regional marketing and economic promotion" (telephone interview, Head of Administration).

A second example for this type of council would be the Regional Government and Council of Santiago, Chile. This council is divided into two bodies working reciprocally. The Regional Government of Santiago de Chile-on the one hand-is responsible for the administration of the region and is concerned with the balanced and sustainable development of the territory. Its main task is the planning and preparation of projects that promote the economic, social and cultural development of the metropolitan region. The Metropolitan Regional Council of Santiago (CORE)—on the other hand-is a political body with normative powers. It is composed of 34 councillors, elected by direct vote of the regions citizens. Whereas every councillor of the regional council represents one local municipality, the staff of the Metropolitan Regional Government is divided into departments, dealing with analysis and guidance, administration and finance, and planning and development.

\subsection{Regional Councils with a Specific Distinct Orientation}

Another type of regional councils, the councils with a distinct topic orientation have been identified by the comparatively weak role democratic legitimation plays in that regional councils (see Figure 5), accompanied by the regional councils' role as symbolic and development supporting level. Two different types of regional councils with a specific distinct orientation have been identified: Symbolic regional councils and regional councils with an economic focus.

\section{COUNCILS WITH A SPECIFIC DISTINCT ORIENTATION}
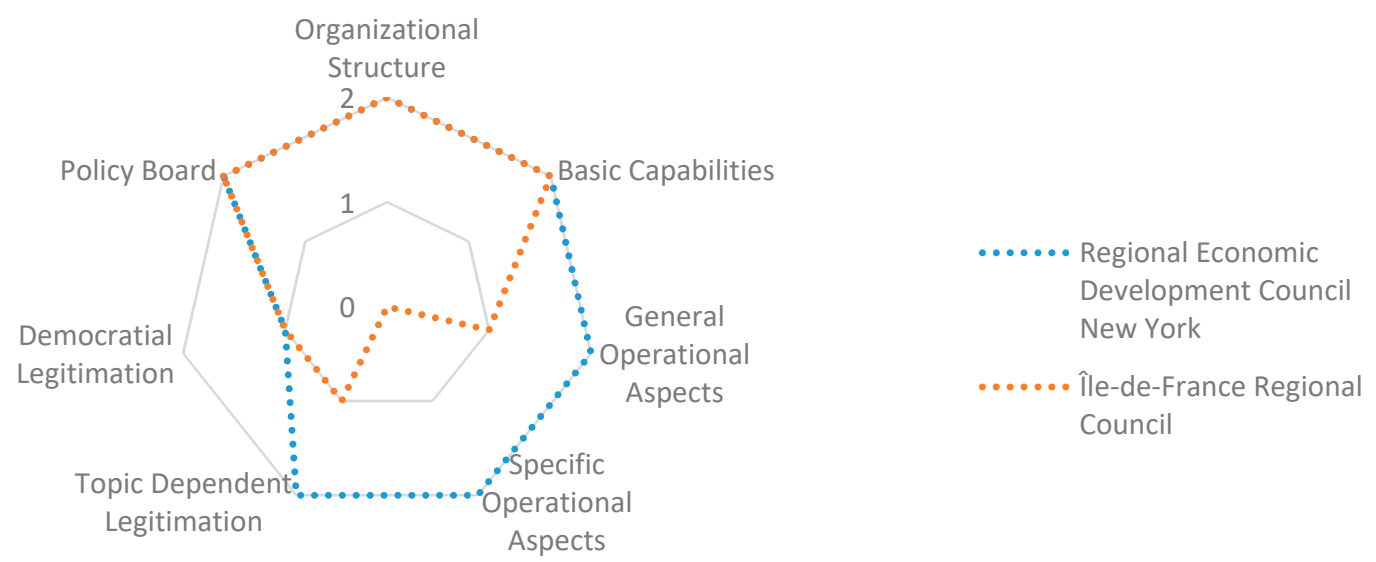

Figure 5. Radar charts for councils with a specific distinct orientation. Source: own design. 
Symbolic regional councils do not have any executive or legislative power. The identified case region is the Regional Council Île-de-France, France. The case of the Regional Council Île-de-France rather illustrates the willingness to overcome centralism. "The regional level in France has very limited power with regard to legal power, political capacities, financial capacities, compared to what can be observed in other countries, mainly Europe. This can be explained by the fact that the region is the youngest territorial unit in the French system, compared to municipalities and departments. Regions were created as a territorial unit at the time of the decentralization reforms in the 1980s. So, the region remains a territorial level that is somewhat artificial" (telephone interview, President of the Governance and Public Policy Department, Institute of Planning and Urbanism, Île-de-France region).

Therefore, symbolic councils can act as mediators between the state level and the community level, continuing to delegate the national states' decisions to the municipal level. The Regional Council Île-de-France, France, for example, has undertaken the first steps to turn away from the traditionally centralized political structure in France. As the regional level in France is very young, the creation and the well-organized structure of the council can be seen as its main strength. The Regional Council Île-de-France is responsible for the organization of public transport in the region. However, projects planned by the council are not realized or financed by the council itself. Because of the limited legislative and executive power the council can be seen as symbolic first step to overcome structures and to create new governance levels.

Regional councils with an economic focus aim to synergize strategic spatial decisions (where in the region spending money for what purpose) and the means to realize these strategies (providing funds) within a regional context. One example for this type of regional council is the Regional Economic Development Council New York, United States. This council focusses on improving the business climate and the expansion of economic growth by investing or supporting investments that enforce interconnecting strategies. To maximize the regions industrial and innovation assets the council invites and supports businesses, academic institutions, and other independent organizations to connect with each other and thus to optimize economic growth.

Both councils, the Regional Council Île-de-France and the Regional Economic Development Council New York, have in common that the councils focus is not laid on democratically legitimized political decision making. Both councils do not decide on comprehensive responsibilities of public administration on their own. The generation of new ideas, the transfer of knowledge between different types of actors and between different horizontal levels of governance, as well as the motivation to strengthen regional cooperation are the primary aims.

\subsection{Regional Councils with General Administrative Functions}

The last type of regional councils covers councils not having a distinct specialization but rather supporting local municipalities. This is supported by the following quote of the Waterloo Regional Council, emphasising the importance of municipal cooperation: "The council brings everyone together-three cities and four townships-so that we know each other. And if there is a sudden emergency, we can collaborate very quickly with a high level of comfort due to our experience with each other" (questionnaire, Regional Councillor of the Waterloo Regional Council).

Another aspect of the councils with general administrative functions is providing infrastructure and services: "Then there are the administrative aspects [ ... ] that, for a city like Montevideo, implies many things: for example, the issue of improving city cleanliness [ ... ]. Also, there's work on completing the sewage system, which is another issue we are working very hard on" (telephone interview, Adviser to the Direction of Economic Development \& Regional Integration, Intendancy of Montevideo). Therefore, this type of council is identified as a council with general administrative functions.

Interestingly, with regard to the legitimation of regional councils and with regard to operational aspects, none of the regional councils with general administrative functions shows an above average value in the subcategory of topic dependent legitimation and in the subcategory of highly specific 
operational aspects. This is mirrored in the radar charts of the respective councils (see Figure 6). The figure also shows that the variety of councils with general administrative functions is very broad.

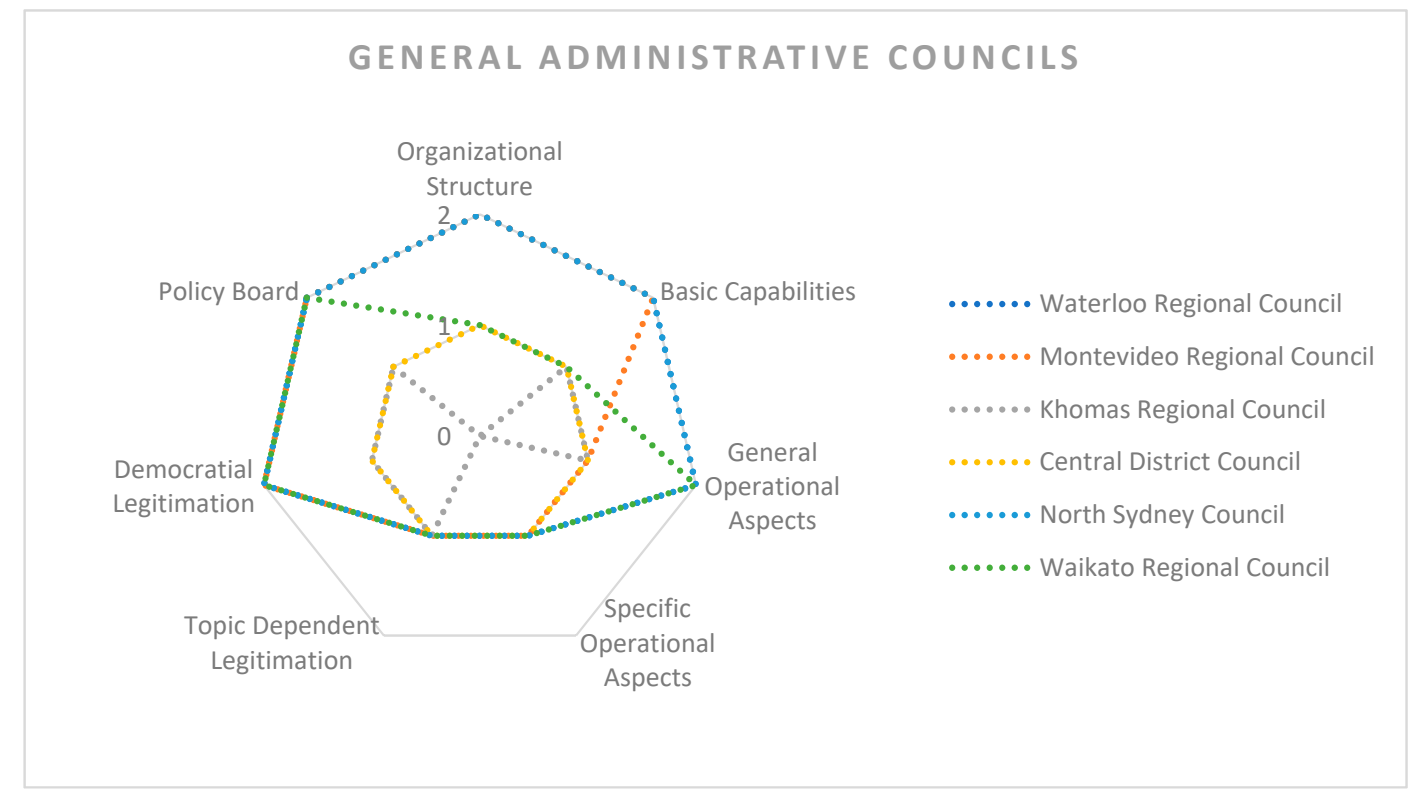

Figure 6. Radar charts for councils with general administrative functions. Source: own design.

The majority of the analysed regional councils could be identified as councils with general administrative functions. The regional councils of Waterloo, Montevideo, North Sydney, the Khomas, the Central District, and the Waikato Region could be understood as regional councils with general administrative functions.

These councils tend to adopt community-based services and thus operate on a very small scale. They mainly provide everyday services to their local citizens. It is not their main purpose to act strategically on a large scale. They are rather understood as contact partner for local day-to-day issues. Therefore, regional councils with general administrative functions rely on key organizational elements (e.g., in many cases the council's work does include political and technical committees; the council's work is supported through professional in-house staff, and a stable source of funding does exist). However, with regard to the legitimation of regional councils and with regard to operational aspects, comprehensive research on different strategic topics and highly specific operational structures is missing or only existent in parts. The named councils above performed medium within topic dependent legitimation. Specific operational aspects, e.g., encouraging network interaction beyond the activities of the councils itself, were missing in most of the councils with general administrative functions.

However, the variety of missing aspects in councils with general administrative functions is very broad. For example, in some councils the missing elements only cover very few aspects, e.g., in the North Sydney Council, Australia only one aspect (encouraging the use of external resources to use and develop regional social capital) was missing while the council sees itself as part of network governance [57]. By covering several areas of programmatic involvement and by realizing planning projects, the work of the council goes beyond its purely administrative function. However, describing itself as "local government", The North Sydney Council operates on a rather small scale.

Another example for regional councils with general administrative functions is the Central District Council, Botswana. Unlike the example of the North Sydney Council, the Central District Council, Botswana, fulfils aspects of the three types of elements only partly. The financial capacity is especially limited. The operational power is focused upon the fundamental organization of the Central District region. Areas of involvement include basic education, power supply, and social and 
community development. The council concentrates on the development of social aspects and tackles the requirements of the population [58]. Summing up, the council tries to provide a fair basic living standard to the entire region.

\section{Discussion}

The aim of this paper was to understand mechanisms of regional councils in a global context by systemizing and examining categories supporting the success of regional councils. On the basis of scientific literature, three main categories and subcategories have been identified that are discussed to support the success of regional councils. The existence and use of the identified subcategories has been evaluated in ten case regions.

Summarizing the comparative results, all regional councils show key organizational elements as well as aspects of legitimation and operational aspects. However, the exact composition of the all element within the councils differs strongly. The way each council carries out its daily work, the covered topics, as well as the geographic and stakeholder-related focus differs strongly and is dependent on the administrative structure of the national state the council is embedded in the available resources and the legitimation the council has.

Based on the empirical results, three types of reginal councils have been identified: councils with general administrative functions, councils with comprehensive governance functions, and councils with a distinctive focus. Table 5 shows how the identified three types of regional councils depend on the three main categories. In Table 5, the role of the categories for the different council types is summarized.

Table 5. Topics and sample questions of the questionnaire.

\begin{tabular}{|c|c|c|c|}
\hline & Councils with a Distinctive Focus & $\begin{array}{l}\text { Councils with Comprehensive } \\
\text { Governance Functions }\end{array}$ & $\begin{array}{l}\text { Councils with General } \\
\text { Administrative Functions }\end{array}$ \\
\hline $\begin{array}{l}\text { Organizational } \\
\text { elements }\end{array}$ & $\begin{array}{l}\text { To support the topic specific work of } \\
\text { the councils, a stable source of } \\
\text { funding and in-house staff is very } \\
\text { important for this type of council. } \\
\text { A differentiation between (political) } \\
\text { decision making and administrative } \\
\text { work is important as not all councils } \\
\text { rely on democratic legitimation. }\end{array}$ & $\begin{array}{l}\text { To support long-term } \\
\text { comprehensive governance work, } \\
\text { a stable source of funding and } \\
\text { in-house staff is very important } \\
\text { for this type of council. } \\
\text { A differentiation between political } \\
\text { decision making and } \\
\text { administrative work is important } \\
\text { to support democratically } \\
\text { legitimized comprehensive } \\
\text { governance mechanisms. }\end{array}$ & $\begin{array}{l}\text { A differentiation between political } \\
\text { decision making and } \\
\text { administrative work is important } \\
\text { to support a long-term orientated } \\
\text { administrative work of the council. } \\
\text { The dimension of potential } \\
\text { funding sources and the number } \\
\text { of in-house staff varies according } \\
\text { the socio-economic situation of } \\
\text { the respective nation states. }\end{array}$ \\
\hline Legitimation & $\begin{array}{l}\text { Democratic legitimation by elected } \\
\text { councillors to govern the region is not } \\
\text { the main focus. Legitimation } \\
\text { develops through the topic dependent } \\
\text { work to support the region. }\end{array}$ & $\begin{array}{l}\text { Democratic legitimation by } \\
\text { elected councillors to govern the } \\
\text { region is important as the councils } \\
\text { have the possibility to govern in } \\
\text { the region. The topics covered are } \\
\text { important to demonstrate how } \\
\text { effective and important the } \\
\text { council works. However, the topic } \\
\text { dependent work does not have to } \\
\text { legitimate the council. }\end{array}$ & $\begin{array}{l}\text { Democratic legitimation by } \\
\text { elected councillors to govern the } \\
\text { region or by including elected } \\
\text { councillors in decision-making } \\
\text { processes is important to support } \\
\text { the acceptance of the } \\
\text { administrative work. }\end{array}$ \\
\hline Operational aspects & $\begin{array}{l}\text { The importance of operational aspects } \\
\text { varies heavily. Symbolic councils do } \\
\text { not necessarily carry out operational } \\
\text { work. These role of these councils is } \\
\text { to symbolize the regional level in a } \\
\text { multi-level-system. For other councils, } \\
\text { focussing on specific topics like } \\
\text { economic development, } \\
\text { the operational aspects are of } \\
\text { high importance. }\end{array}$ & $\begin{array}{l}\text { To support comprehensive } \\
\text { governance functions, general } \\
\text { operational aspects (like an } \\
\text { all-region-focus and transparent } \\
\text { governance regulations) are as } \\
\text { important as specific governance } \\
\text { functions that foster interaction } \\
\text { beyond the regional council, } \\
\text { e.g., with citizens and through } \\
\text { network activities. }\end{array}$ & $\begin{array}{l}\text { The emphasis on administrative } \\
\text { functions leads to a focus on } \\
\text { general operational aspects. } \\
\text { Activities supporting operational } \\
\text { structures and networks beyond } \\
\text { the regional administrative } \\
\text { structure are important but do not } \\
\text { have the same importance as } \\
\text { general operational aspects. }\end{array}$ \\
\hline
\end{tabular}

With regard to the developed analytical framework it can be concluded that the three types of elements for successful regional councils developed here offer a fruitful starting point to analyse regional councils or to develop regional councils further. Within all selected regions the three main elements can be found at least partly whereas only two regional councils fulfil all possible criteria within the main elements: the Stuttgart Regional Council in Germany and the Metropolitan Regional 
Council of Santiago in Chile. Therefore analytical framework enables an application on mature regional councils (e.g., Stuttgart and Santiago) and developing regional councils. This is also important because councils that do not have or aim for a full coverage of all sub-aspects of three main elements can work successfully with a more detailed focus on fewer topics.

Depending on the number of councils picking up sub-aspects of the three elements, the most important criteria are executive powers that are made up of elected local officials providing policy leadership at a regional level and the existence of basic capabilities, mainly in-house professional staff that is capable of providing administrative and technical support and a stable source of funding. According to the number of councils based on these elements and on the analysis of documents, interviews, and questionnaires, these are the most important criteria supporting the well-functioning of the selected regional councils. The content worked on by the regional councils, however, has to be defined by the councillors and the executive involved in the council. Most councils work on a similar set of topics (mainly economic competitiveness, sustainable development with a focus on reducing disparities within the region, transport and, partly, water and energy supply). For actually carrying out the work, a network of partners within the region is helpful, enabling the use of external (to the regional council) resources. However, to bring together a range of stakeholders a clear aim for the work as well as a clear framework, controlling the work, are necessary. Therefore these criteria could be a starting point of new regional councils.

Based on the results of this paper, further research could evaluate the three identified main categories supporting the success of regional councils in more detail. This research has been conducted as a first attempt to understand the functioning of regional councils by systematizing categories to analyse success factors of regional councils. However, further indicators could be developed. Another possibility to deepen the understanding of regional councils is to expand the analytical focus on sample regions and to systematize the selected regions according to the political system, the socio-economic system and the decentralization of power in the respective nation states.

Author Contributions: Conceptualization, A.G. and M.J.; methodology, A.G.; investigation, M.J.; writing-original draft preparation, M.J.; writing-review and editing, A.G.; supervision, A.G.; project administration, A.G.; funding acquisition, A.G.

Funding: This research was conducted in a joint project with and funded by the King Salman Center for Local Governance (KSCLG), Riyadh.

Conflicts of Interest: The authors declare no conflicts of interest. Staff of the KSCLG helped gaining information through interviews and internet research. The funders had no further role in the design of the study; in the interpretation of the presented data; in the writing of the manuscript, or in the decision to publish the results.

\section{References}

1. United Nations. World Urbanization Prospects, the 2014 Revision. Highlights; United Nations: New York, NY, USA, 2014; Available online: https:/ / esa.un.org/unpd/wup/publications / files/wup2014-highlights.Pdf (accessed on 14 February 2019).

2. Zimmermann, K.; Heinelt, H. Metropolitan Governance in Deutschland. Regieren in Ballungsräumen und neue Formen politischer Steuerung; VS Verlag für Sozialwissenschaften: Wiesbaden, Germany, 2012.

3. Portney, K.E. Taking Sustainable Cities Seriously. Economic Development, the Environment, and Quality of Life in American Cities, 2nd ed.; The MIT Press: Cambridge, UK, 2013.

4. European Cities \& Towns Towards Sustainability. Aalborg Charta: Charter of European Cities \& Towns Towards Sustainability. Available online: http:/ / www.sustainablecities.eu/fileadmin/repository / Aalborg_ Charter/Aalborg_Charter_English.pdf (accessed on 12 December 2018).

5. Jonas, A.E.G. City-regionalism: Questions of distribution and politics. Prog. Hum. Geogr. 2012, 36, 822-829. [CrossRef]

6. Jonas, A.E.G. City-Regionalism as a Contingent 'Geopolitics of Capitalism'. Geopolitics 2013, 18, $284-298$. [CrossRef]

7. Growe, A. Where do KIBS workers work in Germany?: Shifting patterns of KIBS employment in metropoles, regiopoles and industrialised hinterlands. Erdkunde 2016, 70, 201-215. [CrossRef] 
8. Growe, A. Emerging polycentric city-regions in Germany. Regionalisation of economic activities in metropolitan regions. Erdkunde 2012, 66, 295-311. [CrossRef]

9. Kim, J.H.; Jurey, N. Local and Regional Governance Structures. J. Plan. Lit. 2013, 28, 111-123. [CrossRef]

10. Miller, D.Y.; Lee, J.H. Making Sense of Metropolitan Regions: A Dimensional Approach to Regional Governance. Publius J. Fed. 2010, 41, 126-145. [CrossRef]

11. Harrison, J.; Hoyler, M. Governing the new metropolis. Urban Stud. 2014, 51, 2249-2266. [CrossRef]

12. Growe, A.; Münter, A. Die Renaissance der großen Städte. Geogr. Rundsch. 2010, 62, 54-59.

13. Ziafati Bafarasat, A. Exploring new systems of regionalism: An English case study. Cities 2016, 50, 119-128. [CrossRef]

14. Bafarasat, A.Z.; Baker, M. Strategic spatial planning under regime governance and localism: Experiences from the North West of England. Town Plan. Rev. 2016, 87, 681-703. [CrossRef]

15. Harrison, J.; Growe, A. From places to flows? Planning for the new 'regional world' in Germany. Eur. Urban Reg. Stud. 2014, 21, 21-41. [CrossRef]

16. Harrison, J.; Growe, A. When regions collide: In what sense a new 'regional problem'? Environ. Plann. A 2014, 46, 2332-2352. [CrossRef]

17. Scott, A.J. Regions and the World Economy. The Coming Shape of Global Production, Competition, and Political Order; Repr. New as Paperback; Oxford Univ. Pr: Oxford, MI, USA, 2000.

18. Scott, A.J.; Agnew, J.; Soja, E.W.; Storper, M. Global City-Regions. In Global City-Regions: Trends, Theory, Policy; Repr.; Scott, A.J., Ed.; Oxford University Press: Oxford, UK, 2004; pp. 11-30.

19. Blatter, J. From 'spaces of place' to 'spaces of flows'? Territorial and functional governance in cross-border regions in Europe and North America. Int. J. Urban Reg. Res. 2004, 28, 530-548. [CrossRef]

20. Keating, M. The New Regionalism in Western Europe. Territorial Restructuring and Political Change; Elgar: Cheltenham, PA, USA, 1998.

21. Jones, M.; Paasi, A. Guest Editorial: Regional World(s): Advancing the Geography of Regions. Reg. Stud. 2013, 47, 1-5. [CrossRef]

22. Harrison, J. Configuring the New 'Regional World': On being Caught between Territory and Networks. Reg. Stud. 2012, 47, 55-74. [CrossRef]

23. Harrison, J. Re-reading the new regionalism: A sympathetic critique. Space Polity 2006, 10, 21-46. [CrossRef]

24. Growe, A.; Volgmann, K. Exploring Cosmopolitanity and Connectivity in The Polycentric German Urban System. Tijdschr. Econ. Soc. Geogr. 2016, 107, 214-231. [CrossRef]

25. Münter, A.; Volgmann, K. The Metropolization and Regionalization of the Knowledge Economy in the Multi-Core Rhine-Ruhr Metropolitan Region. Eur. Plan. Stud. 2014, 22, 2542-2560. [CrossRef]

26. Growe, A. Raummuster unterschiedlicher Wissensformen. Der Einfluss von Transaktionskosten auf Konzentrationsprozesse wissensintensiver Dienstleister im deutschen Städtesystem. Raumforsch Raumordn 2012, 70, 175-190. [CrossRef]

27. Wagner, M.; Mager, C.; Schmidt, N.; Kiese, N.; Growe, A. Conflicts about urban green spaces in metropolitan areas under conditions of climate change: A multidisciplinary analysis of stakeholders' negotiations in planning processes. Urban Sci. 2019, 3, 15. [CrossRef]

28. Ross, C.L. (Ed.) Megaregions. Planning for Global Competitiveness; Island Press: Washington, DC, USA, 2009.

29. Ross, C.L.; Lee, D.J.-H.; Meijers, E.; Welch, T. (Eds.) Megaregions, Prosperity and Sustainability. Spatial Planning for Future Prosperity and Sustainability; Routledge: London, UK, 2015.

30. Growe, A. Knoten in Netzwerken Wissensintensiver Dienstleistungen. Eine Empirische Analyse des Polyzentralen Deutschen Städtesystems; Rohn: Detmold, Germany, 2012.

31. Fricke, C. Metropolitan Regions as a Changing Policy Concept in a Comparative Perspective. Raumforsch Raumordn 2016. [CrossRef]

32. Harrison, J.; Hoyler, M. Megaregions: Foundations, frailties, futures. In Megaregions: Globalization's New Urban Form? Harrison, J., Hoyler, M., Eds.; Edward Elgar Publishing: Cheltenham, UK, 2015; pp. 1-28.

33. Kwon, S.-W.; Park, S.-C. Metropolitan Governance: How Regional Organizations Influence Interlocal Land Use Coordination. J. Urban Aff. 2016, 36, 925-940. [CrossRef]

34. Stead, D. The Rise of Territorial Governance in European Policy. Eur. Plan. Stud. 2013, 22, 1368-1383. [CrossRef]

35. Wolf, J.F.; Bryan, T.K. Identifying the Capacities of Regional Councils of Government. State Local Gov. Rev. 2009, 41, 61-68. [CrossRef] 
36. Gualini, E.; Fricke, C. 'Who governs' Berlin's metropolitan region?: The strategic-relational construction of metropolitan scale in Berlin-Brandenburg's economic development policies. Environ. Plan. C Politics Space 2018, 7, 239965441877654. [CrossRef]

37. Visser, J.A. Voluntary Regional Councils and the New Regionalism. J. Plan. Educ. Res. 2004, 24, 51-63. [CrossRef]

38. Grigsby, J.E. Regional governance and regional councils. Nat Civ. Rev 1996, 85, 53-58. [CrossRef]

39. Bryan, T.K.; Wolf, J.F. Soft Regionalism in Action: Examining Voluntary Regional Councils' Structures, Processes and Programs. Public Organ. Rev. 2010, 10, 99-115. [CrossRef]

40. Visser, J.A. Understanding Local Government Cooperation in Urban Regions. Am. Rev. Public Adm. 2016, 32, 40-65. [CrossRef]

41. Heinelt, H.; Zimmermann, K. 'How Can We Explain Diversity in Metropolitan Governance within a Country?' Some Reflections on Recent Developments in Germany. Int. J. Urban Reg. Res. 2011, 35, 1175-1192. [CrossRef]

42. Koschatzky, K.; Uyarra, E.; Héraud, J.-A. Understandind the Multi-Level, Multi-Actor Governance of Regions for Developing New Policy Designs. Available online: http:/ / www.prime-noe.org/conference-presentations, 92.html (accessed on 11 March 2016).

43. EU Committee of the Regions. Governance of Metropolitan Regions. European and Global Experiences; Workshop on the "Governance of Metropolitan Regions in Federal Systems": Brüssel, Belgium, 2011; Available online: http:/ / espas.eu/orbis/sites/default/files/generated/document/en/Consolidated\% 20version\%20-\%20Metropolitan\%20Governance\%20-\%20final.pdf (accessed on 14 November 2015).

44. Organisation for Economic Co-Operation and Development. Regional Development Policies in OECD Countries; OECD Publishing: Paris, France, 2010.

45. Zonneveld, W. In search of conceptual modernization: The new Dutch 'national spatial strategy'. J. Hous. Built Environ. 2005, 20, 425-443. [CrossRef]

46. Dühr, S. Illustrating spatial policies in Europe. Eur. Plan. Stud. 2003, 11, 929-948. [CrossRef]

47. Hamilton, D.K. Measuring the Effectiveness of Regional Governing Systems. A Comparative Study of City Regions in North America; Springer: New York, NY, USA, 2013.

48. Gualini, E. The rescaling of governance in Europe: New spatial and institutional rationales. Eur. Plan. Stud. 2006, 14, 881-904. [CrossRef]

49. Mose, I.; Jacuniak-Suda, M.; Fiedler, G. Regional Governance-Stile in Europa. Eine vergleichende Analyse von Steuerungsstilen ausgewählter LEADER-Netzwerke in Extremadura (Spanien), Warmińsko-Mazurskie (Polen) und Western Isles (Schottland). Raumforsch Raumordn 2014, 72, 3-20. [CrossRef]

50. Fricke, C. Spatial Governance across Borders Revisited: Organizational Forms and Spatial Planning in Metropolitan Cross-border Regions. Eur. Plan. Stud. 2014, 23, 849-870. [CrossRef]

51. Blatter, J. Metropolitan Governance in Deutschland: Normative, utilitaristische, kommunikative und dramaturgische Steuerungsansätze. Swiss Political Sci. Rev. 2005, 11, 119-155. [CrossRef]

52. Dühr, S.; Stead, D.; Zonneveld, W. The Europeanization of spatial planning through territorial cooperation. Plan. Pract. Res. 2007, 22, 291-307. [CrossRef]

53. Balchin, P.N.; Sykora, L.; Bull, G.H. Regional Policy and Planning in Europe; Routledge: London, UK; New York, NY, USA, 1999.

54. Blotevogel, H.H.; Danielzyk, R.; Münter, A. Spatial planning in Germany: Institutional inertia and new challenges. In Spatial Planning Systems and Practices in Europe: A Comparative Perspective on Continuity and Changes; Reimer, M., Getimis, P., Blotevogel, H.H., Eds.; Routledge: London, UK, 2014; pp. 83-108.

55. Pahl-Weber, E.; Henckel, D. (Eds.) The Planning System and Planning Terms in Germany. A Glossary; Verl. der ARL: Hannover, Germany, 2008.

56. Benz, A. Regional Governance mit organisatorischem Kern: Das Beispiel der Region Stuttgart. Inf. Zur Raumentwickl. 2003, 8, 505-512.

57. Marshall, N.; Dollery, B.; Witherby, A. Regional organisations of councils (ROCS): The emergence of network governance in metropolitan and rural Australia? Australas. J. Reg. Stud. 2003, 9, 169-188.

58. Söderbaum, F. Modes of Regional Governance in Africa: Neoliberalism, Sovereignty Boosting, and Shadow Networks. Glob. Gov. 2004, 10, 419-436. [CrossRef]

(C) 2019 by the authors. Licensee MDPI, Basel, Switzerland. This article is an open access article distributed under the terms and conditions of the Creative Commons Attribution (CC BY) license (http://creativecommons.org/licenses/by/4.0/). 